\title{
Distribution of Aquatic Diptera larvae of Yeşilırmak River (Turkey) and ecological characteristics
}

\author{
Yeşilırmak Nehri'ndeki Sucul Diptera (Insecta) larvalarının dağılımı ve ekolojik \\ özellikleri
}

\section{Özge Başoren ${ }^{\text {** }}$ • Nilgün Kazanc।²}

1Department of Biology, Faculty of Science, Hacettepe University, 06800, Ankara, Turkey

https://orcid.org/0000-0003-3424-6423 2Department of Biology, Faculty of Science, Hacettepe University, 06800, Ankara, Turkey

iD $h$ ttps://orcid.org/0000-0002-2554-7999

Corresponding author: ozzzge@gmail.com

Received date: 22.03 .2020

Accepted date: 18.06 .2020

How to cite this paper:

Başoren, Ö. \& Kazancı, N. (2020). Distribution of Aquatic Diptera larvae of Yeşilırmak River (Turkey) and ecological characteristics. Ege Journal of Fisheries and Aquatic Sciences, 37(4), 397-407. DOI: 10.12714/egejfas.37.4.11

Abstract: Yeşilırmak River is one of the most important running waters of Turkey, but the water quality of this river has been affected by agricultural and domestic pollution. Dams and hydroelectric power plants also threaten the habitat quality and biodiversity of the river. This research contains investigation of Diptera fauna in Yeşilırmak River and tributaries, determination ecological characteristics of the collecting sites according to System A and System B Classification of Water Framework Directive (WFD), assessment of water quality of the studied sites by measuring the physicochemical variables (water temperature, $\mathrm{pH}$, electrical conductivity, dissolved oxygen, $\mathrm{NO}_{2}-\mathrm{N}, \mathrm{NO}_{3}-\mathrm{N}, \mathrm{NH}_{4}-\mathrm{N}, \mathrm{PO}_{4}-\mathrm{P}$ ) and using some metrics (abundance, number of taxa, Simpson Diversity Index, Shannon-Wiener Diversity Index, Margalef Diversity Index, Evenness). Thirty-three (33) sites were sampled from Yeşilırmak River and its tributaries in June 2010. Diptera individuals were detected in 20 of them. Two thousand four hundred forty-five (2445) individuals belonging to 12 families and 16 taxa were identified in 20 sampling sites. The water quality classes of the studied sites were Class III (moderate pollution) and Class IV (heavily pollution) according to values of physicochemical variables.

Keywords: Habitat degradation, physicochemical variables, true flies, water quality, water pollution

Öz: Yeşilırmak Nehri, Türkiye'nin en önemli nehirlerinden biridir. Ancak nehrin su kalitesi tarımsal ve evsel kirlilikten etkilenmektedir. Ayrıca, barajlar ve hidroelektrik santralleri de nehrin habitat kalitesini ve biyoçeşitliliğini tehdit etmektedir. Bu çalışmayla, Yeşilırmak Nehri ve kollarındaki Diptera komunitesi belirlenmiş, Su Çerçeve Direktifi (SÇD)'nin Sistem Ave B sınıflandırmasına göre çalışılan istasyonların ekolojileri tespit edilmiş, fizikokimyasal değişkenler (su sıcaklığı, pH, elektriksel iletkenlik, çözünmüş oksijen, $\mathrm{NO}_{2}-\mathrm{N}, \mathrm{NO}_{3}-\mathrm{N}, \mathrm{NH}_{4}-\mathrm{N}, \mathrm{PO}_{4}-\mathrm{P}$ ) ve bazı metrikler (bolluk, taksa sayısı, Simpson Çeşitlilik İndeksi Shannon-Wiener Çeşitlilik İndeksi, Margalef Çeşitlilik İndeksi) kullanılarak istasyonların su kaliteleri değerlendirilmiştir. Yeşilırmak Nehri ve kollarında, Haziran 2010 tarihinde otuz üç (33) istasyon örneklenmiş, bu istasyonlardan 20 tanesinde Diptera bireylerine rastlanmıştır. Bu 20 örnekleme istasyonundan Diptera takımına ait 16 taksa, 12 familya, 2445 birey tanımlanmıştır. İstasyonların su kaliteleri, fizikokimyasal değişkenlere göre III. Sınıf (orta kirli) ve IV. Sınıf (çok kirli) olarak belirlenmiştir.

Anahtar kelimeler: Fizikokimyasal değişkenler, habitat bozulması, sinekler, su kalitesi, su kirliliği

\section{INTRODUCTION}

Diptera have a worldwide distribution and comprise nearly 46.000 described aquatic species (Adler and Courtney, 2019). Diptera larvae are among the most abundant members in almost all aquatic ecosystems. They are found in a variety of aquatic habitats (springs, streams, rivers, lakes) (Adler and Courtney, 2019). Aquatic flies are important in aquatic food webs and play a significant role in the processing and cycling of nutrients in lentic and lotic environments (Wotton and Malmqvist, 2001).

The European Water Framework Directive (WFD), which is accepted by the European Union Member States in 2000 (Council of European Communities, 2000), aims to prevent and improve aquatic ecosystems deterioration, to protect and restore all water bodies and to conserve water resources in Europe. Biological assessment and monitoring of water quality is very important for WFD studies. Benthic macroinvertebrates are the most commonly used organisms for biomonitoring the quality of aquatic habitats (Johnson et al., 2006; Rosenberg and Resh, 1993). In Turkey, WFD studies using macroinvertebrates has increased in last 10 years (Akay and Dalkıran, 2019; Arslan, Salur, et al., 2016; Arslan, Kökçü, et al., 2016; Başören and Kazancı, 2016; Bolat et al., 2016; Duran and Akyildiz, 2011; Ekingen and Kazancl, 2012; Kazanci, Başören, et al., 2013; Kazanci, Ekingen, et al., 2010; Kazanci, Türkmen, et al., 2010, 2013, 2015, 2017; Kazanci and Ertunç, 2010; Türkmen and Kazancı, 2015, 2016; Zeybek, 2017; Zeybek et al., 2014).

Diptera taxa are the most widely used like the other benthic macroinvertebrates in freshwater biomonitoring studies (Courtney et al., 2017; Paine et al., 1956). Some taxa are very sensitive and cannot tolerate water pollution, while some taxa are extremely tolerant and survive in heavily 
polluted water (Adler and Courtney, 2019; Bouchard, 2004; Kazancı and Ertunç, 2010; Luoto, 2011). However, there are limited studies about the larval ecology of most Diptera species in the world (Wagner et al., 2008).

Yeşilırmak River is one of the important rivers in Turkey. But the habitat quality of this river has been threatened with increasing pollutant loads due to contamination from agricultural, industrial, and domestic waste in recent years. There are 19 dams and hydroelectric power plants on the river basin (Kazanci, Türkmen, et al., 2010). Deterioration of the riverbed, habitat loss, change in water quality, temperature and flow regime caused by the dams are the other important problems in the Yeşilırmak River and its tributaries. These impacts are the main causes of loss of biodiversity in freshwater habitats. All these negative activities in Yeşilırmak River Basin also negatively affect the community structure and habitats of Diptera.
The purpose of this study is to investigate the Diptera fauna of the Yeşillımak River and tributaries, to determine ecological characteristics of the collecting sites according to System A and System B Classification of WFD, to assess the water quality of the collecting sites by measuring the physicochemical variables and using some metrics (abundance, number of taxa, Simpson Diversity Index, Shannon-Wiener Diversity Index, Margalef Diversity Index, Evenness).

\section{MATERIAL AND METHODS}

Yeşilırmak River is located in the northeastern Turkey and it is the second longest river. The catchment area of Yeşilımak River is $38,730 \mathrm{~km}^{2}$, which is about $5 \%$ of Turkey's surface area. It rises from Köse Mountain in the north of Sivas, flows approximately $519 \mathrm{~km}$ and reaches to the Black Sea. Çekerek, Kelkit, Tersakan and Salhan are the tributaries of the Yeşilırmak River.

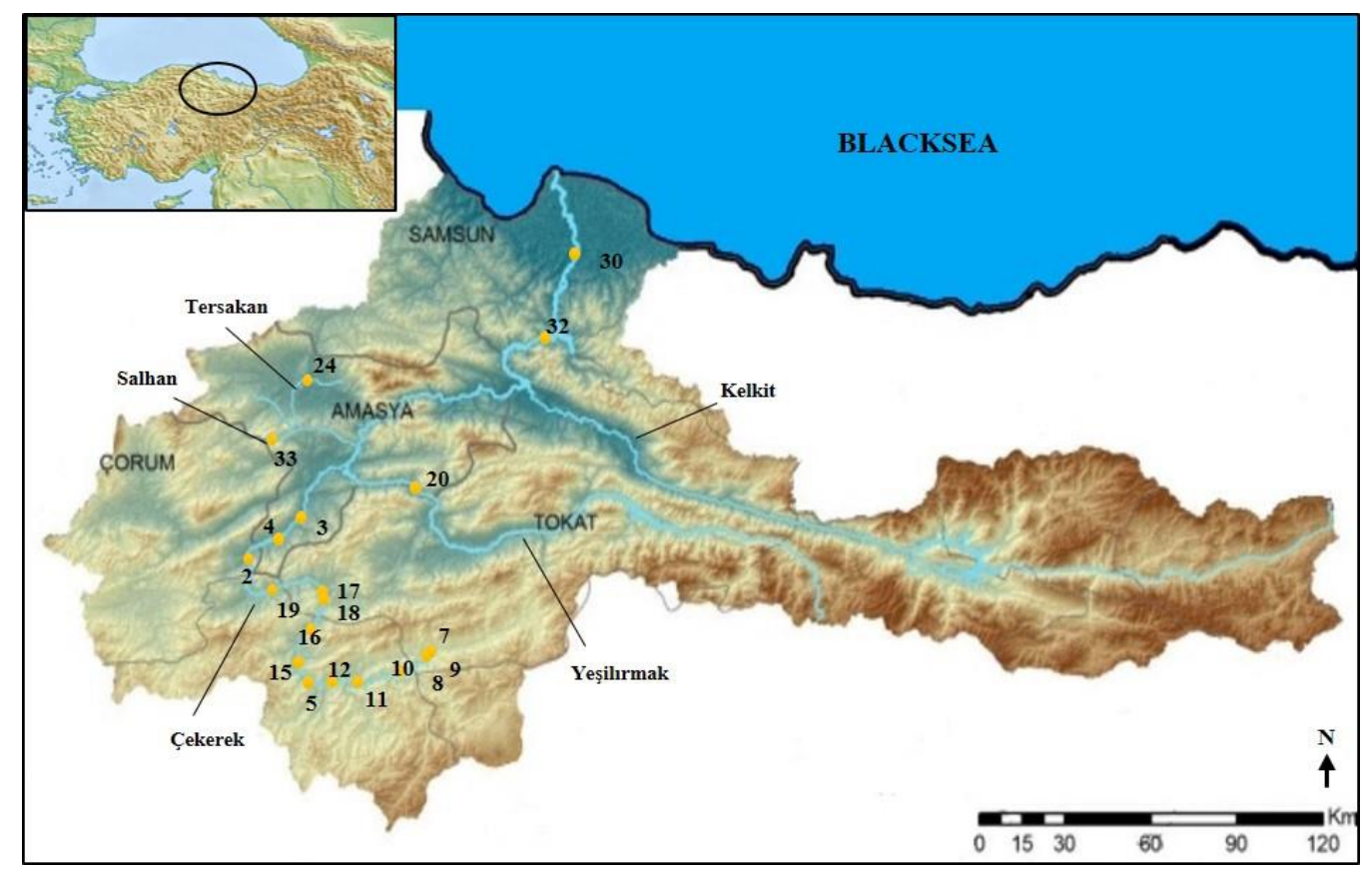

Figure 1. Sampling sites of Yeşilırmak River and its tributaries

Thirty-three (33) sites were sampled from Yeşilırmak River and its tributaries in June 2010 (Figure 1). Diptera individuals were detected in 20 of them. Geographical coordinates of these sites were given in Table 4. Some physicochemical variables and geological characteristics were recorded in collecting sites. Water temperature, $\mathrm{pH}$, electrical conductivity, and dissolved oxygen were measured in the field by using an YSI 556 multi-probe system. In addition, $\mathrm{NO}_{2}-\mathrm{N}, \mathrm{NO}_{3}-\mathrm{N}, \mathrm{NH}_{4}-\mathrm{N}$, and $\mathrm{PO}_{4}-\mathrm{P}$ were measured using a Hach DR/890 Datalogging Colorimeter $(\mathrm{HACH}$, 2005). The water quality classes of the studied sites were evaluated by using the Surface Water Quality Regulation Annex-5 (Anonymous, 2015, 2016) (Table 3).
Diptera samples were collected by a standard pond net. Samples were preserved in $80 \%$ ethyl alcohol. Leica MZ75 stereomicroscope and Olympus CX21FS1 binocular microscope were used for identifications. Three diversity indices (Simpson Diversity Index, Shannon-Wiener Diversity Index and Margalef Diversity Index) were also used to determine water quality. Biological data were analyzed by using ASTERICS (AQEM/STAR Ecological River Classification System) software (AQEM Consortium, 2006) and all samples (including 1 individual) were taken into account for this analysis. 
Certain geological and physical characteristics of sampling sites required by System $A$ and System B classifications of WFD were given in Table 4.

\section{RESULTS}

Two thousand four hundred forty-five (2445) individuals belonging to 12 families and 16 taxa were identified in 20 sampling sites (Table 1). According to this table, the most common families of Diptera were Chironomidae, Pediciidae, Simuliidae and Tipuliidae with a wide range of tolerance.

The abundance values and number of taxa of 20 sites were given in Table 2. The highest abundance value (439) was found in Site 3 while the lowest abundance value (2) was found in Site 5, 16 and 20. The highest taxa number (7) was found in Site 8, 15 and 18 while the lowest taxa number (1) was found in Site 4, 5, 16 and 20. According to Table 2, the values of Simpson Diversity Index, Shannon-Wiener Diversity Index and Margalef Diversity Index varied between 0 and $0.689 ; 0$ and $1.341 ; 0$ and 1.377 , respectively.

The results of the physicochemical variables (water temperature, $\mathrm{pH}$, electrical conductivity, dissolved oxygen concentration, $\mathrm{NO}_{2}-\mathrm{N}, \mathrm{NO}_{3}-\mathrm{N}, \mathrm{NH}_{4}-\mathrm{N}$, and $\mathrm{PO}_{4}-\mathrm{P}$ ) and the water quality classes of the 20 sites were given in Figure 2, Figure 3 and Table 3.

Table 1. List of taxa in the studied sites

\begin{tabular}{|c|c|c|c|c|c|c|c|c|c|c|c|c|c|c|c|c|c|c|c|c|c|}
\hline & & 2 & 3 & 4 & 5 & 7 & 8 & 9 & 10 & 11 & 12 & 15 & 16 & 17 & 18 & 19 & 20 & 24 & 30 & 32 & 33 \\
\hline Chironomidae & Gen. sp. & * & * & & & $*$ & * & * & * & * & * & * & * & * & * & * & * & * & $*$ & * & $*$ \\
\hline Blephariceridae & Liponeura & & & & & & & * & & & & & & & & & & & & & \\
\hline Dixidae & Dixa & & & & & * & & & & & & & & & & & & & & & \\
\hline Dolicopodidae & Gen. sp. & & * & & & & & & & & * & & & & & & & * & $*$ & & * \\
\hline Empididae & Clinocera & & & & & & * & * & & * & * & & & & & & & & & & \\
\hline \multirow[t]{3}{*}{ Limoniidae } & Gen. sp. & & & & & & & & * & * & & & & & * & * & & & & & \\
\hline & Erioptera & & & & & & & & & & & * & & & & & & & & & \\
\hline & Hexatoma & & & & & & * & & * & * & & * & & & & * & & & & & \\
\hline \multirow[t]{2}{*}{ Muscidae } & Limnophora & * & & & & & & & & & & & & & & & & & & & \\
\hline & Lispe & & & & & & & & & & & & & & & & & & * & & \\
\hline \multirow[t]{2}{*}{ Pediciidae } & Dicranota & & & & * & * & * & * & * & & * & * & & * & * & & & & & & \\
\hline & Pedicia & & & & & & & & & & & & & & * & & & & & & \\
\hline Simuliidae & Simulium & * & $*$ & & & * & * & * & * & * & * & $*$ & & * & * & & & $*$ & * & & * \\
\hline Stratiomyidae & Oxycera & & & & & & * & & & & & * & & & & & & & & & \\
\hline Tabanidae & Tabanus & & & * & & & * & & & & & * & & & * & & & & & & \\
\hline Tipulidae & Tipula & * & & & & & & & & & * & & & & * & & & ${ }^{*}$ & ${ }^{*}$ & ${ }^{*}$ & * \\
\hline
\end{tabular}

Table 2. Values of indices of the sites at Yeşilırmak River

\begin{tabular}{|c|c|c|c|c|c|c|c|c|c|c|}
\hline Metric & 2 & 3 & 4 & 5 & 7 & 8 & 9 & 10 & 11 & 12 \\
\hline $\begin{array}{l}\text { Abundance } \\
{\left[\text { ind } / \mathrm{m}^{2}\right]}\end{array}$ & 325 & 439 & 3 & 2 & 32 & 78 & 157 & 73 & 232 & 136 \\
\hline Number of Taxa & 4 & 3 & 1 & 1 & 4 & 7 & 5 & 5 & 5 & 6 \\
\hline Simpson Diversity Index & 0.326 & 0.398 & 0 & 0 & 0.629 & 0.689 & 0.527 & 0.578 & 0.58 & 0.598 \\
\hline $\begin{array}{l}\text { Shannon-Wiener } \\
\text { Diversity Index }\end{array}$ & 0.554 & 0.627 & 0 & 0 & 1.125 & 1.341 & 0.82 & 1.125 & 0.988 & 1.129 \\
\hline Margalef Diversity Index & 0.519 & 0.329 & 0 & 0 & 0.866 & 1.377 & 0.791 & 0.932 & 0.734 & 1.018 \\
\hline Pielou's Evenness Index & 0.399 & 0.571 & $N C^{*}$ & $N C^{*}$ & 0.811 & 0.689 & 0.509 & 0.699 & 0.614 & 0.63 \\
\hline Metric & 15 & 16 & 17 & 18 & 19 & 20 & 24 & 30 & 32 & 33 \\
\hline $\begin{array}{l}\text { Abundance } \\
\left.\text { [ind } / \mathrm{m}^{2}\right]\end{array}$ & 30 & 2 & 5 & 357 & 14 & 2 & 134 & 313 & 17 & 94 \\
\hline Number of Taxa & 7 & 1 & 3 & 7 & 3 & 1 & 4 & 5 & 2 & 4 \\
\hline Simpson Diversity Index & 0.508 & 0 & 0.67 & 0.274 & 0.275 & 0 & 0.115 & 0.439 & 0.118 & 0.36 \\
\hline $\begin{array}{l}\text { Shannon-Wiener } \\
\text { Diversity Index }\end{array}$ & 1.114 & 0 & 0.95 & 0.564 & 0.509 & 0 & 0.27 & 0.726 & 0.224 & 0.688 \\
\hline Margalef Diversity Index & 1.302 & 0 & 1.243 & 1.021 & 0.758 & 0 & 0.613 & 0.696 & 0.353 & 0.66 \\
\hline Pielou's Evenness Index & 0.572 & $N C^{*}$ & 0.865 & 0.29 & 0.463 & $N C^{*}$ & 0.195 & 0.451 & 0.323 & 0.496 \\
\hline
\end{tabular}

${ }^{*} \mathrm{NC}$ : Not calculated 


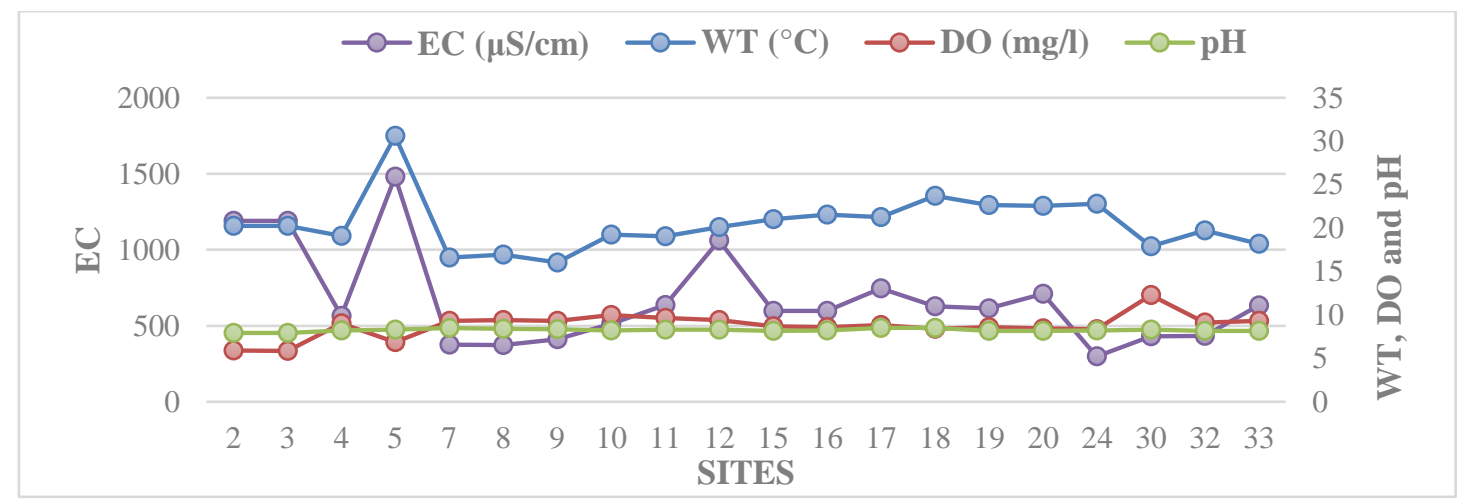

Figure 2. Values of water temperature $\left({ }^{\circ} \mathrm{C}\right)$, dissolved oxygen $(\mathrm{mg} / \mathrm{L}), \mathrm{pH}$ and electrical conductivity $(\mu \mathrm{S} / \mathrm{cm})$

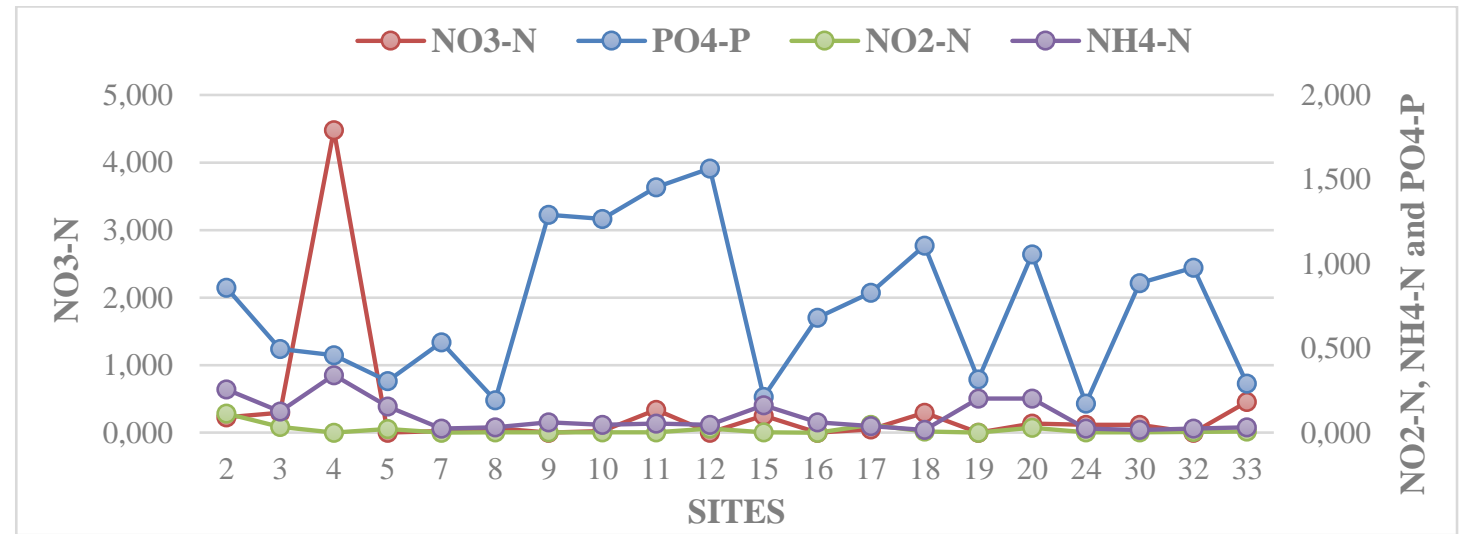

Figure 3. Values of $\mathrm{NO}_{2}-\mathrm{N}(\mathrm{mg} / \mathrm{L}), \mathrm{NO}_{3}-\mathrm{N}(\mathrm{mg} / \mathrm{L}), \mathrm{NH}_{4}-\mathrm{N}(\mathrm{mg} / \mathrm{L})$, and $\mathrm{PO}_{4}-\mathrm{P}(\mathrm{mg} / \mathrm{L})$

Table 3. Water quality classes of the studied sites according to the physicochemical variables (Anonymous, 2015; 2016)

\begin{tabular}{|c|c|c|c|c|c|c|c|c|c|c|}
\hline Site & Site name & $\begin{array}{l}\text { WT } \\
\left({ }^{\circ} \mathrm{C}\right)\end{array}$ & $\begin{array}{c}\mathrm{DO} \\
(\mathrm{mg} / \mathrm{l})\end{array}$ & $\mathrm{pH}$ & $\begin{array}{c}E C \\
(\mu S / c m)\end{array}$ & $\begin{array}{l}\mathrm{PO}_{4}-\mathrm{P} \\
(\mathrm{mg} / \mathrm{l})\end{array}$ & $\begin{array}{l}\mathrm{NO}_{3}-\mathrm{N} \\
(\mathrm{mg} / \mathrm{l})\end{array}$ & $\begin{array}{l}\mathrm{NO}_{2}-\mathrm{N} \\
(\mathrm{mg} / \mathrm{l})\end{array}$ & $\begin{array}{l}\mathrm{NH}_{4}-\mathrm{N} \\
(\mathrm{mg} / \mathrm{l})\end{array}$ & $\begin{array}{c}\text { Final Water } \\
\text { Quality Class }\end{array}$ \\
\hline 2 & Çekerek-2 & 1 & III & I & III & IV & I & III & $\|$ & IV \\
\hline 3 & Çekerek-3 & 1 & III & I & III & III & I & $\|$ & I & III \\
\hline 4 & Çekerek-4 & I & I & I & $\|$ & III & $\|$ & I & $\|$ & III \\
\hline 5 & Çekerek-5 & IV & $\|$ & 1 & III & III & I & $\|$ & I & IV \\
\hline 7 & Çekerek-7 & I & I & 1 & I & III & I & I & I & III \\
\hline 8 & Çekerek-8 & I & I & 1 & I & III & I & I & I & III \\
\hline 9 & Çekerek-9 & 1 & I & I & $\|$ & IV & I & I & I & III \\
\hline 10 & Çekerek-10 & I & I & 1 & $\|$ & IV & I & I & I & III \\
\hline 11 & Çekerek-11 & I & I & I & $\|$ & IV & I & I & I & IV \\
\hline 12 & Çekerek-12 & I & I & 1 & III & IV & I & $\|$ & I & IV \\
\hline 15 & Çekerek-15 & I & I & I & $\|$ & III & I & I & I & III \\
\hline 16 & Çekerek-16 & I & I & 1 & $\|$ & IV & I & I & I & IV \\
\hline 17 & Çekerek-17 & I & I & I & $\|$ & IV & I & $\|$ & I & IV \\
\hline 18 & Çekerek-18 & 1 & I & I & $\|$ & IV & I & 1 & I & IV \\
\hline 19 & Çekerek-19 & I & I & I & $\|$ & III & I & I & $\|$ & III \\
\hline 20 & Yeşilırmak-1 & I & I & I & $\|$ & IV & I & $\|$ & $\|$ & IV \\
\hline 24 & Tersakan Çayı - 1 & I & I & 1 & I & III & I & I & I & $\|$ \\
\hline 30 & Yeşilırmak-2 & I & I & I & $\|$ & IV & I & I & I & IV \\
\hline 32 & Yeşilırmak-4 & 1 & I & I & $\|$ & IV & I & I & I & IV \\
\hline 33 & Salhan Çayı - 1 & I & I & I & $\|$ & III & I & I & I & III \\
\hline
\end{tabular}

(WT: temperature, DO: dissolved oxygen, EC: electrical conductivity) 
Yeşilırmak River and its tributaries were alkaline, with $\mathrm{pH}$ values between 7.92 and 8.51 . The water temperature values recorded were between 16.04 and $30.6^{\circ} \mathrm{C}$. The dissolved oxygen values recorded were between 5.85 and $12.27 \mathrm{mg} / \mathrm{l}$. The electrical conductivity values recorded were between 298 and $1480 \mu \mathrm{S} / \mathrm{cm}$. Nitrite nitrogen values ranged between 0 and $0.113 \mathrm{mg} / \mathrm{l}$. Nitrate nitrogen values ranged between 0 and $4.480 \mathrm{mg} / \mathrm{l}$. Ammonium nitrogen values ranged between
0.016 and $0.341 \mathrm{mg} / \mathrm{l}$. Orthophosphate phosphorus values ranged between 0 and $1.565 \mathrm{mg} / \mathrm{l}$. According to nitrogen and phosphorus concentrations, studied sites were impacted by agricultural activities.

Some geological and physical characteristics of the 20 sites, required by System A and System B of WFD were given in Table 4.

Table 4. Geological and physical characteristics of sampling sites according to System A and System B Classification of WFD

\begin{tabular}{|c|c|c|c|c|c|c|c|}
\hline Sites & 2 & 3 & 4 & 5 & 7 & 8 & 9 \\
\hline Ecoregion (System A) & Y & $Y$ & Y & Y & Y & Y & Y \\
\hline Altitude (System A) & $\begin{array}{l}\text { Medium } \\
(200 \mathrm{~m}-800 \mathrm{~m})\end{array}$ & $\begin{array}{c}\text { Medium } \\
(200 \mathrm{~m}-800 \mathrm{~m})\end{array}$ & $\begin{array}{c}\text { Medium } \\
(200 \mathrm{~m}-800 \mathrm{~m})\end{array}$ & $\begin{array}{l}\text { Medium } \\
(200 \mathrm{~m}-800 \mathrm{~m})\end{array}$ & High (>800m) & High (>800m) & High (>800m) \\
\hline Altitude (System B) & $526 m$ & $576 m$ & $427 m$ & $580 m$ & $1206 m$ & $1239 m$ & $1227 m$ \\
\hline $\begin{array}{l}\text { Catchment Area } \\
\text { (System A) }\end{array}$ & $\begin{array}{l}\text { Medium } \\
\left(100-1000 \mathrm{~km}^{2}\right)\end{array}$ & $\begin{array}{c}\text { Medium } \\
\left(100-1000 \mathrm{~km}^{2}\right)\end{array}$ & $\begin{array}{c}\text { Medium } \\
\left(100-1000 \mathrm{~km}^{2}\right)\end{array}$ & $\begin{array}{c}\text { Medium } \\
\left(100-1000 \mathrm{~km}^{2}\right)\end{array}$ & $\begin{array}{c}\text { Medium } \\
\left(100-1000 \mathrm{~km}^{2}\right)\end{array}$ & $\begin{array}{c}\text { Medium } \\
\left(100-1000 \mathrm{~km}^{2}\right)\end{array}$ & $\begin{array}{c}\text { Medium } \\
\left(100-1000 \mathrm{~km}^{2}\right)\end{array}$ \\
\hline $\begin{array}{l}\text { Geology } \\
\text { (System A and System B) }\end{array}$ & Siliceous & Siliceous & Siliceous & Siliceous & Siliceous & Siliceous & Siliceous \\
\hline Latitude (System B) & $40^{\circ} 27^{\prime} 18.20^{\prime \prime} \mathrm{N}$ & $40^{\circ} 33^{\prime} 47.87^{\prime \prime} \mathrm{N}$ & $40^{\circ} 32^{\prime} 16.36^{\prime \prime} \mathrm{N}$ & $39^{\circ} 50^{\prime} 45.96^{\prime \prime} \mathrm{N}$ & $40^{\circ} 06^{\prime} 38.11^{\prime \prime} \mathrm{N}$ & $40^{\circ} 06^{\prime} 44.41^{\prime \prime} \mathrm{N}$ & $40^{\circ} 06^{\prime} 39.06^{\prime \prime} \mathrm{N}$ \\
\hline Longitude (System B) & $35^{\circ} 26^{\prime} 59.18^{\prime \prime} \mathrm{E}$ & $35^{\circ} 30^{\prime} 34.89^{\prime \prime} \mathrm{E}$ & $35^{\circ} 39^{\prime} 55.86^{\prime \prime} \mathrm{E}$ & $35^{\circ} 27^{\prime} 00.00^{\prime \prime} \mathrm{E}$ & $36^{\circ} 34^{\prime} 53.52^{\prime \prime} \mathrm{E}$ & $36^{\circ} 35^{\prime} 03.53^{\prime \prime} \mathrm{E}$ & $36^{\circ} 35^{\prime} 00.42^{\prime \prime} \mathrm{E}$ \\
\hline Substratum & $\begin{array}{l}\% 50 \text { rock, } \\
\% 30 \text { stone, } \\
\% 15 \text { gravel, } \\
\% 5 \text { sand }\end{array}$ & $\begin{array}{c}10 \% \text { rock, } \\
25 \% \text { stone, } \\
15 \% \text { gravel, } \\
50 \% \text { sand }\end{array}$ & $\begin{array}{c}10 \% \text { rock, } \\
15 \% \text { stone, } \\
20 \% \text { gravel, } \\
5 \% \text { sand, } \\
50 \% \text { clay }\end{array}$ & $\begin{array}{c}40 \% \text { stone, } \\
40 \% \text { gravel, } \\
5 \% \text { sand, } \\
15 \% \text { clay }\end{array}$ & $\begin{array}{c}20 \% \text { rock, } \\
40 \% \text { stone, } \\
30 \% \text { gravel, } \\
10 \% \text { sand }\end{array}$ & $\begin{array}{c}20 \% \text { rock, } \\
40 \% \text { stone, } \\
30 \% \text { gravel, } \\
10 \% \text { sand }\end{array}$ & $\begin{array}{c}40 \% \text { rock, } \\
35 \% \text { stone, } \\
20 \% \text { gravel, } \\
5 \% \text { sand }\end{array}$ \\
\hline Stream Zone & Epirhithron & Epirhithron & Metarhithron & Metarhithron & Epirhithron & Epirhithron & Epirhithron \\
\hline Riparian vegetation & $100 \%$ & $80 \%$ & $90 \%$ & $50 \%$ & $90 \%$ & $100 \%$ & $100 \%$ \\
\hline $\begin{array}{l}\text { Stream width } \\
\text { in dry period }\end{array}$ & $5 m$ & $1,5 \mathrm{~m}$ & $25 m$ & $5 m$ & $50 \mathrm{~cm}$ & $1,5 \mathrm{~m}$ & $2 m$ \\
\hline $\begin{array}{l}\text { Stream width } \\
\text { in wet period }\end{array}$ & $15 m$ & $1,5 \mathrm{~m}$ & $40 m$ & $7 \mathrm{~m}$ & $1 \mathrm{~m}$ & $2 m$ & $2 m$ \\
\hline Sites & 10 & 11 & 12 & 15 & 16 & 17 & 18 \\
\hline Ecoregion (System A) & Y & Y & Y & Y & Y & Y & Y \\
\hline Altitude (System A) & High (>800m) & High (>800m) & High (>800m) & $\begin{array}{l}\text { Medium } \\
(200 \mathrm{~m}-800 \mathrm{~m})\end{array}$ & $\begin{array}{l}\text { Medium } \\
(200 \mathrm{~m}-800 \mathrm{~m})\end{array}$ & High (>800m) & High (>800m) \\
\hline Altitude (System B) & $1153 m$ & $1054 m$ & $1117 m$ & $777 m$ & $756 m$ & $869 m$ & $874 m$ \\
\hline $\begin{array}{l}\text { Catchment Area } \\
\text { (System A) }\end{array}$ & $\begin{array}{c}\text { Medium } \\
\left(100-1000 \mathrm{~km}^{2}\right)\end{array}$ & $\begin{array}{c}\text { Medium } \\
\left(100-1000 \mathrm{~km}^{2}\right)\end{array}$ & $\begin{array}{c}\text { Medium } \\
\left(100-1000 \mathrm{~km}^{2}\right)\end{array}$ & $\begin{array}{c}\text { Medium } \\
\left(100-1000 \mathrm{~km}^{2}\right)\end{array}$ & $\begin{array}{c}\text { Medium } \\
\left(100-1000 \mathrm{~km}^{2}\right)\end{array}$ & $\begin{array}{c}\text { Medium } \\
\left(100-1000 \mathrm{~km}^{2}\right)\end{array}$ & $\begin{array}{l}\text { Medium } \\
\left(100-1000 \mathrm{~km}^{2}\right)\end{array}$ \\
\hline $\begin{array}{l}\text { Geology } \\
\text { (System A and System B) }\end{array}$ & Siliceous & Siliceous & Siliceous & Siliceous & Siliceous & Siliceous & Siliceous \\
\hline Latitude (System B) & $40^{\circ} 05^{\prime} 42.73^{\prime \prime} \mathrm{N}$ & $40^{\circ} 00^{\prime} 36.82^{\prime \prime} \mathrm{N}$ & $40^{\circ} 01^{\prime} 27.53^{\prime \prime} \mathrm{N}$ & $40^{\circ} 05^{\prime} 17.43^{\prime \prime} \mathrm{N}$ & $40^{\circ} 09^{\prime} 44.71 " \mathrm{~N}$ & $40^{\circ} 20^{\prime} 40.79^{\prime \prime} \mathrm{N}$ & $40^{\circ} 20^{\prime} 39.51$ ' N \\
\hline Longitude (System B) & $36^{\circ} 32^{\prime} 23.63^{\prime \prime} \mathrm{E}$ & $36^{\circ} 10^{\prime} 29.57^{\prime \prime} \mathrm{E}$ & $35^{\circ} 48^{\prime} 39.04^{\prime \prime} \mathrm{E}$ & $35^{\circ} 35^{\prime} 14.64^{\prime \prime} \mathrm{E}$ & $35^{\circ} 38^{\prime} 08.86^{\prime \prime} \mathrm{E}$ & $35^{\circ} 41^{\prime} 18.32 " \mathrm{E}$ & $35^{\circ} 41^{\prime} 19.73 " \mathrm{E}$ \\
\hline Substratum & $\begin{array}{c}5 \% \text { stone } \\
60 \% \text { gravel, } \\
25 \% \text { sand, } \\
10 \% \text { clay }\end{array}$ & $\begin{array}{c}15 \% \text { rock, } \\
45 \% \text { stone, } \\
25 \% \text { gravel, } \\
10 \% \text { sand, } \\
5 \% \text { clay }\end{array}$ & $\begin{array}{c}50 \% \text { rock, } \\
15 \% \text { stone, } \\
15 \% \text { gravel, } \\
10 \% \text { sand, } \\
10 \% \text { clay }\end{array}$ & $\begin{array}{c}15 \% \text { stone, } \\
30 \% \text { gravel, } \\
30 \% \text { sand, } \\
25 \% \text { clay }\end{array}$ & $\begin{array}{c}20 \% \text { rock, } \\
30 \% \text { stone, } \\
30 \% \text { gravel, } \\
10 \% \text { sand, } \\
10 \% \text { clay }\end{array}$ & $\begin{array}{c}50 \% \text { rock, } \\
15 \% \text { stone, } \\
15 \% \text { gravel, } \\
10 \% \text { sand, } \\
10 \% \text { clay }\end{array}$ & $\begin{array}{c}50 \% \text { rock, } \\
15 \% \text { stone, } \\
15 \% \text { gravel, } \\
10 \% \text { sand, } \\
10 \% \text { clay }\end{array}$ \\
\hline Stream Zone & Epirhithron & Metarhithron & Epirhithron & Metarhithron & Metarhithron & Epirhithron & Epirhithron \\
\hline Riparian vegetation & $100 \%$ & $70 \%$ & $100 \%$ & $100 \%$ & $90 \%$ & $100 \%$ & $100 \%$ \\
\hline $\begin{array}{l}\text { Stream width } \\
\text { in dry period }\end{array}$ & $2 m$ & $4 m$ & $50 \mathrm{~cm}$ & $10 \mathrm{~m}$ & $30 m$ & $50 \mathrm{~cm}$ & $60 \mathrm{~cm}$ \\
\hline $\begin{array}{l}\text { Stream width } \\
\text { in wet period }\end{array}$ & $12 m$ & $12 m$ & $50 \mathrm{~cm}$ & $30 m$ & $30 m$ & $50 \mathrm{~cm}$ & $60 \mathrm{~cm}$ \\
\hline
\end{tabular}


Table 4. continued

\begin{tabular}{|c|c|c|c|c|c|c|}
\hline Sites & 19 & 20 & 24 & 30 & 32 & 33 \\
\hline Ecoregion (System A) & Y & Y & Y & Y & $Y$ & $Y$ \\
\hline Altitude (System A) & $\begin{array}{l}\text { Medium } \\
(200 \mathrm{~m}-800 \mathrm{~m})\end{array}$ & $\begin{array}{c}\text { Medium } \\
(200 \mathrm{~m}-800 \mathrm{~m})\end{array}$ & High $(>800 \mathrm{~m})$ & Lowland $(<200 \mathrm{~m})$ & Lowland (<200m) & $\begin{array}{c}\text { Medium } \\
(200 \mathrm{~m}-800 \mathrm{~m})\end{array}$ \\
\hline Altitude (System B) & $476 \mathrm{~m}$ & $285 \mathrm{~m}$ & $841 \mathrm{~m}$ & $22 m$ & $77 \mathrm{~m}$ & $520 \mathrm{~m}$ \\
\hline $\begin{array}{l}\text { Catchment Area } \\
\text { (System A) }\end{array}$ & $\begin{array}{c}\text { Medium } \\
\left(100-1000 \mathrm{~km}^{2}\right)\end{array}$ & $\begin{array}{c}\text { Medium } \\
\left(100-1000 \mathrm{~km}^{2}\right)\end{array}$ & $\begin{array}{c}\text { Medium } \\
\left(100-1000 \mathrm{~km}^{2}\right)\end{array}$ & $\begin{array}{c}\text { Medium } \\
\left(100-1000 \mathrm{~km}^{2}\right)\end{array}$ & $\begin{array}{c}\text { Medium } \\
\left(100-1000 \mathrm{~km}^{2}\right)\end{array}$ & $\begin{array}{c}\text { Medium } \\
(100-1000 \mathrm{~km} 2)\end{array}$ \\
\hline $\begin{array}{l}\text { Geology } \\
\text { (System A and System B) }\end{array}$ & Siliceous & Siliceous & Siliceous & Siliceous & Siliceous & Siliceous \\
\hline Latitude (System B) & $40^{\circ} 23^{\prime} 44.44^{\prime \prime} \mathrm{N}$ & $40^{\circ} 44^{\prime} 52.12^{\prime \prime} \mathrm{N}$ & $40^{\circ} 57^{\prime} 06.36^{\prime \prime} \mathrm{N}$ & $41^{\circ} 06^{\prime} 49.76^{\prime \prime} \mathrm{N}$ & $40^{\circ} 56^{\prime} 33.44^{\prime \prime} \mathrm{N}$ & $40^{\circ} 45^{\prime} 18.72^{\prime \prime} \mathrm{N}$ \\
\hline Longitude (System B) & $35^{\circ} 32^{\prime} 09.75^{\prime \prime} \mathrm{E}$ & $36^{\circ} 08^{\prime} 42.72^{\prime \prime} \mathrm{E}$ & $35^{\circ} 57^{\prime} 54.46^{\prime \prime} \mathrm{E}$ & $36^{\circ} 42^{\prime} 51.42^{\prime \prime} \mathrm{E}$ & $36^{\circ} 38^{\prime} 51.98^{\prime \prime} \mathrm{E}$ & $35^{\circ} 29^{\prime} 29.76^{\prime \prime} \mathrm{E}$ \\
\hline Substratum & $\begin{array}{c}10 \% \text { rock, } \\
30 \% \text { stone, } \\
20 \% \text { gravel, } \\
20 \% \text { sand, } \\
20 \% \text { clay }\end{array}$ & $\begin{array}{c}30 \% \text { rock, } \\
30 \% \text { stone, } \\
20 \% \text { gravel, } \\
10 \% \text { sand, } \\
10 \% \text { clay }\end{array}$ & $\begin{array}{c}10 \% \text { rock, } \\
40 \% \text { stone, } \\
40 \% \text { gravel, } \\
10 \% \text { sand }\end{array}$ & $\begin{array}{c}10 \% \text { rock, } \\
40 \% \text { stone, } \\
40 \% \text { gravel, } \\
10 \% \text { sand }\end{array}$ & $\begin{array}{c}10 \% \text { rock, } \\
35 \% \text { stone, } \\
30 \% \text { gravel, } \\
30 \% \text { sand }\end{array}$ & $\begin{array}{c}5 \% \text { rock, } \\
30 \% \text { stone, } \\
50 \% \text { gravel, } \\
15 \% \text { sand }\end{array}$ \\
\hline Stream Zone & Metarhithron & Hiporhithron & Metarhithron & Epipotamon & Hipopotamon & Epirhithron \\
\hline Riparian vegetation & $70 \%$ & $100 \%$ & $80 \%$ & $60 \%$ & $60 \%$ & $90 \%$ \\
\hline $\begin{array}{l}\text { Stream width } \\
\text { in dry period }\end{array}$ & $10 \mathrm{~m}$ & $30 \mathrm{~m}$ & $5 \mathrm{~m}$ & $80 \mathrm{~m}$ & $17 \mathrm{~m}$ & $2 m$ \\
\hline $\begin{array}{l}\text { Stream width } \\
\text { in wet period }\end{array}$ & $20 \mathrm{~m}$ & $40 \mathrm{~m}$ & $5 \mathrm{~m}$ & $100 \mathrm{~m}$ & $25 \mathrm{~m}$ & $7 \mathrm{~m}$ \\
\hline
\end{tabular}

\section{DISCUSSION AND CONCLUSION}

Yeşilırmak is one of the 25 major basins in Turkey but the water quality of the river has been affected by various anthropogenic activities. The most important pollution sources of the Yeşilırmak River are agricultural activities, urban waste waters and sewage. Moreover, physical destruction, dams and hydroelectric power plants also threaten to habitat quality of the river. The values of physicochemical variables were negatively affected by all these activities. The water quality classes of the studied sites were Class III (9 sites) and Class IV (11 sites) according to values of physicochemical variables.

Benthic macroinvertebrates are most useful bioindicators in monitoring studies because they are sensitive to changes in the ecosystem and reflect the aquatic habitat quality (Johnson et al., 2006; Rosenberg and Resh, 1993). Aquatic Diptera is an important group of the benthic macroinvertebrate fauna (Adler and Courtney, 2019).

The families Chironomidae, Pediciidae, Simuliidae and Tipulidae are the most frequently collected families in the studied sites. These families with a high tolerance range could spread over a larger area. Some genera and species of the family Chironomidae prefer in oligosaprobic sites with high water quality but they are mostly found in betamezosaprobic and alfamezosaprobic habitats with low water quality (Epler, 2001; Gültutan and Kazancl, 2009). They can be used as bioindicators to assess changes in aquatic ecosystems and habitat quality because they are abundant, species-diverse insect group and show different level of sensitivity to habitat degradation (Armitage et al., 1995; Ferrington, 2008). The family Chironomidae was found in almost all sites in this study. This family was found extensively in Site 2, 3, 11, 24 and 30. Site 2, 11 and 30 have Class IV water quality and were heavily polluted. Site 3 and 24 have Class III water quality and were moderately polluted. All these sites were surrounded by agricultural areas. Habitat degradation was also detected in stream bed in Site 11 and 30 .

The family Simuliidae is widespread in freshwater habitats. The composition of black fly larvae and pupae is affected by various environmental variables (riparian vegetation, substrate types, current velocity, dissolved oxygen, temperature, etc.) of streams (Lautenschläger and Kiel, 2005; Malmqvist et al., 1999). This family is also commonly used as biological indicators, together with Chironomidae (Adriaenssens et al., 2004; Feld et al., 2002; Kazancı and Ertunç, 2010). In this study, only Simulium sp. was identified as belonging to this family. Larvae and pupae of Simulium sp. (Simuliidae) are generally found in betamesosaprobic habitats, but they can be inhabited in oligosaprobic and alphamesosaprobic habitats (CSN 75 7716, 1998; Kazancı and Ertunç, 2008; Lechthaler et al., 2017). Stream zonation preferences of this genus are hyporhithron, epipotamon and metapotamon zone of streams (Car et al., 1995). Simuliidae was the second common family in the study area. Simulium sp. was found extensively in Site 3 and 18 in this study. Site 3 has Class III water quality and was moderately polluted. Habitat degradation was detected in the stream beds of this site and it affected by nutrient inputs from agricultural areas. Site 18 has Class IV water quality and was 
heavily polluted. This site was located far from agricultural and urban areas. A periodic situation may have caused the low water quality.

The ecology and distribution of Tipulidae are poorly known. Most of them live in aquatic (bottom of streams) or semiaquatic habitats (margins of small rivers, wet mosses) (Gelhaus, 1986). In this study, only Tipula sp. was identified as belonging to this family. Tipula sp. prefers mainly alphamesosaprobic habitats but it is also found in betamesosaprobic and polysaprobic habitats (CSN 75 7716, 1998). Stream zonation preferences of this genus are epirhithron, metarhithron and hyporhithron but it also occur in littoral zone of streams (AQEM Consortium, 2002). This genus was more common in Site 30 . This site has Class IV water quality and was heavily polluted. Site 30 is the closest site to the river mouth. This site was surrounded by agricultural areas that contribute large nutrient loads to running water.

The families Pediciidae and Limoniidae prefer similar environmental conditions (Reusch and Oosterbroek, 1997). Larvae of these families are found a wide variety of habitats (rapidly flowing streams, brackish water, intertidal zones) and they can tolerate environmental changes (Bulankova, 2003; Reusch and Oosterbroek, 1997). In this study, Dicranota sp. and Pedicia sp. were identified as belonging to family Pediciidae. Dicranota sp. prefers generally oligosaprobic and betamesosaprobic habitats but it also found in xenosaprobic and alphamesosaprobic habitats (Šporka, 2003). Stream zonation preferences of this genus are metarhithron and hyporhithron but it also occur in epirhithron and epipotamon zone of streams (AQEM Consortium, 2002). This genus was more common in Site 8 and 12. Site 8 has Class III water quality and was moderately polluted. This site was situated close to the source of Çekerek Stream. Site 12 has Class IV water quality and was heavily polluted. Although these sites were located far from agricultural, urban and industrial influences, they have low water quality. Another genus belonging to Pediciidae was Pedicia sp. in this study. There is little information about the ecology of Pedicia sp. in the literature. Some larval specimens of this genus were recorded from springs and headwater with low temperatures (Ujvárosi \& Bálint, 2012; Ujvárosi et al., 2010). In this study, one individual of this genus was found only in Site 18. This site has Class IV water quality and was heavily polluted. Site 18 was not affected by agricultural and urban pollution like Site 8 and 12. A periodic situation may have caused the low water quality.

In this study, Erioptera sp. and Hexatoma sp. were identified as belonging to family Limoniidae. Despite that, Hexatoma sp. is one of the largest and also most widely distributed genus of this family, the information about preimaginal stages is inadequate (Podeniene and Gelhaus, 2015). Hexatoma sp. prefers oligosaprobic and betamesosaprobic habitats (CSN 757716,1998$)$. This genus was more common in Site 10. Another genus belonging to
Limoniidae was Erioptera sp. in this study. Ecological information of this genus is poorly known. Larvae of Erioptera can live in a wide variety of substrates such as sand, moss, mud at the water margin (Kolcsár et al., 2017). In this study, one individual of this genus was found only in Site 15. Site 10 has Class IV water quality and was heavily polluted. Site 15 has Class III water quality and were moderately polluted. These sites were affected by agricultural and domestic activities. They were also situated after dams and physical destructions were detected in the stream beds. Releasing water from dams affected values of physicochemical variables and benthic macroinvertebrate community. Therefore, Erioptera sp. was probably drifted from the upstream parts of the stream to this site.

The larvae of Blephariceridae with ventral suction disc can inhabit in fast flowing water (Courtney and Merritt, 2008). Because larval blepharicerids are important component of stream habitat and they mostly found in clean, cold streams with high dissolved oxygen, they can be used as bioindicators for assessing the habitat quality of aquatic ecosystems (Courtney et al., 2017; Frutiger and Niederhauser, 2000; Zwick, 1977). In this study, only Liponeura sp. was identified as belonging to this family. Liponeura sp. prefers mainly oligosaprobic habitats but it is also found in xenosaprobic habitats (CSN 75 7716, 1998). Stream zonation preference of this genus is epirhithron (Schmedtje and Colling, 1996). One individual of this genus was found only in Site 9. This site has Class IV water quality and was heavily polluted. Site 9 was situated close to the source of Çekerek Stream. The reason for the low water quality is probably a periodic and temporary situation.

The family Dixidae with only two genera, Dixa and Dixella, is one of the smallest families of Diptera in Palearctic Region. They predominate in clean waters and headwater sites (Ivković and Ivanković, 2019; Wagner et al., 2008). In this study, Dixa sp. was identified as belonging to this family. It prefers generally oligosaprobic and betamesosaprobic habitats but it also found in xenosaprobic and alphamesosaprobic habitats (CSN 75 7716, 1998). Stream zonation preferences of this genus are crenon, epirhithron and metarhithron zone of streams (Tachet et al., 2010). This genus was found only in Site 7. This site has Class III water quality and was moderately polluted. Although Site 7 was situated near the source of Çekerek stream, it has low the water quality. This situation is probably seasonal.

The larvae of Dolichopodidae occur in a wide variety of stream habitats. They prefer mostly betamesosaprobic habitats, but they also found in oligosaprobic and alphamesosaprobic habitats. The family Dolichopodidae has wide range of stream zonation preferences from crenon to metapotamon (Tachet et al., 2010; Wagner et al., 2008). The individuals of this family were more common in Site 3 and 33. These sites have Class III water quality and were moderately polluted. Habitat deterioration was detected in the stream beds of these two sites and they were affected by nutrient inputs from agricultural areas. 
The larvae of Empididae are abundant in running water habitats and have been found in a variety of habitats (Thirion, 2016). In this study, only Clinocera sp. was identified as belonging to this family. It prefers xenosaprobic and oligosaprobic habitats and stream zonation preference of this genus is hyporhithron but it also occur in metarhithron and epipotamon (Schmedtje and Colling, 1996). This genus was more common in Site 12. Although this site is not close to agricultural or urban areas, it has Class IV water quality and was heavily polluted. This is probably a periodic and temporary situation.

The family Muscidae is one of the largest groups of Diptera. Members of this family are found in all zoogeographic regions but aquatic larvae of Muscidae are poorly known (Hilsenhoff, 2001; Wagner et al., 2008). In this study, Limnophora sp. and Lispe sp. were identified as belonging to this family. Limnophora sp. prefers mainly oligosaprobic and betamesosaprobic habitats but it is also found in xenosaprobic habitats (CSN 75 7716, 1998). This genus was found only in Site 2. Another genus belonging to Muscidae was Lispe sp. in this study. There is no information about the ecology of Lispe sp. in the literature. This genus was found only in Site 30 . Site 2 and 30 have Class IV water quality and were heavily polluted. These sites were affected by the agricultural run-off from the surrounding areas and habitat destruction were detected in the stream beds. In site 2, sampling was carried out after rainfalls. Therefore, Limnophora sp. may be drifted to Site 2, which did not have suitable conditions for this species. Site 30 was situated on the main branch of Yeşilırmak River and it is the closest site to the river mouth. It could be said that Lispe sp. can survive in organically polluted water and prefers potamon zone of streams.

The family Stratiomyidae has a worldwide distribution but ecological information about aquatic larvae of this family are quite limited (Hilsenhoff, 2001). In this study, Oxycera sp. was identified as belonging to this family. This genus occurs in clean running waters and it prefers hypocrenon zone of streams (AQEM Consortium, 2002; Kovac and Rozkošný, 2005). It was found in Site 8 and 15. These sites have Class III water quality and were moderately polluted. Site 8 was situated close to the source of Çekerek Stream. Although the physical conditions of this site are suitable for Oxycera sp., the water quality is low according to physicochemical variables. This is probably temporary situation. Site 15 after the dam was affected by agricultural and domestic pollutants. Oxycera sp. was probably drifted from upstream to this site because of releasing water from the dam.

The larvae of Tabanidae are found in a wide variety of aquatic environments (Middlekauff and Lane, 1980). In this study, Tabanus sp. was identified as belonging to this family. This genus prefers mainly betamesosaprobic habitats but it is also found in oligosaprobic and alphamesosaprobic habitats (CSN 75 7716, 1998). Tabanus sp. was found in Site 4, 8, 15 and 18. Site 4, 8 and 15 have Class III water quality and were moderately polluted. Site 18 has Class IV water quality and was heavily polluted. Site 8 was situated close to the source of Çekerek Stream. Site 8 and 18 were located far from agricultural and urban areas. A temporary situation may have caused the low water quality. Site 4 was situated close to the agricultural areas and the sampling was carried out after heavy rainfalls. This led to increased nutrient pollution. The values of nitrate nitrogen (4.480 $\mathrm{mg} / \mathrm{l})$ and ammonium nitrogen $(0.341 \mathrm{mg} / \mathrm{l})$ were the highest in this site. Site 15 were situated after dam and habitat degradation was detected in the stream beds. In addition, settlement was observed around this site.

As mentioned before, although some sites (Site 7, 8, 9, 12, 17 and 18) were situated close to the source of Çekerek Stream and far from agricultural and urban areas, the final water quality of these sites were Class III and IV. The reason for this situation was high $\mathrm{PO}_{4}-\mathrm{P}$ value. The main sources of phosphorus in freshwater and groundwater systems are agricultural fertilizer, domestic and animal waste. Also, phosphorus in groundwater originates from dissolution of minerals that contain phosphate in aquifer sediments (Domagalski and Johnson, 2012; Fuhrer et al., 1999; Holman et al., 2008). According to Dubrovsky et al. (2010), transport of nutrients to streams and groundwaters varies seasonally. The frequent flood events, melting snow during spring and summer months (May - July) accelerates the transport of phosphorus from the soil to the stream by erosion (Dubrovsky et al., 2010; Rekolainen, 1989). Hatch et al. (1999) reported that snowmelt during June caused fluctuations of phosphate concentration in a mountain stream. Probably, the reason for the high $\mathrm{PO}_{4}-\mathrm{P}$ value of Site $7,8,9,12,17$ and 18 were a seasonal situation. Therefore, some of Diptera species may have left these sites and drifted to downstream. Consequently, the information about Diptera fauna and values of physicochemical variables of these sites can be misleading.

Multimetric indices derived from biological data are increasingly used to evaluate the habitat quality and monitor the habitat changes caused by anthropogenic effects (Buss et al., 2015; De Oliveira et al., 2019; Rosenberg and Resh, 1993). Diversity indices are also used for the evaluation of ecological health of streams and the distribution of benthic macroinvertebrates related to habitat quality. Godfrey (1978) reported that these indices are being widely used for assessment of stream pollution research. Biodiversity is defined and measured as an attribute that has two components (richness-number of existing species and evenness-distribution of individuals equally). Biodiversity can serve as an effective indicator of habitat health. Degradation and pollution of natural habitats is strongly associated with decrease in the species richness and evenness of freshwater habitats. In other words, values of the diversity indices decrease with environmental degradation (Godfrey, 1978; Ravera, 2001). 
Simpson Diversity Index, Shannon-Wiener Diversity Index and Margalef Diversity Index were used in this study. Simpson Diversity Index values range between 0 and 1 . The high index value $(>0.6)$ indicates stable communities, while low index value indicates communities under stress conditions (Dash, 2003). The values of Simpson Diversity Index were between $0-0.689$ in this study. According to this index, the highest value was found in Site 8 and the lowest value was found in Site 4, 5, 16 and 20 (Table 2).

Shannon-Wiener Diversity Index is widely used in ecological studies. This index values range between 0 and 5 (Kocataş, 2006). The values above 3.0 mean that the habitat structure is stable and balanced; the values under 1.0 mean that habitat structure is degraded and polluted (Mason, 2002). The values of Shannon-Wiener Diversity Index were between $0-1.341$ in this study. According to this index, the highest value was found in Site 8 and the lowest value was found in Site 4, 5, 16 and 20 (Table 2).

The Margalef Diversity Index is more sensitive to changes in the number of species than number of individuals. Thus, this biodiversity index is different from other biodiversity indices. It has no limit value. The higher species richness values reflect the stability of habitat (Margalef, 1958). The values of Margalef Diversity Index were between 0-1.377 in this study. According to this index, the highest value was found in Site 8 and the lowest value was found in Site 4, 5, 16 and 20 (Table 2).

In these three diversity indices, the highest value belonged to Site 8 , the lowest value belonged to Site $4,5,16$ and 20. Site 8 was situated close to the source of Çekerek Stream and this is one of the sites with the highest number of genera (7). Habitat degradation was not observed in this site. It has Class III water quality and was moderately polluted, but this situation is probably seasonal and temporary. Site 4,5 , 16 and 20 were surrounded by agricultural and urban areas. Site 4 has Class III water quality and was moderately polluted. The sampling was carried out after heavy rainfalls causing an increase in nutrient loading in this site. Site 5, 16

\section{REFERENCES}

Adler, P.H. \& Courtney, G.W. (2019). Ecological and societal services of aquatic Diptera. Insects, 10(3), 70. DOI:10.3390/insects10030070

Adriaenssens, V., Simons, F., Nguyen, L.T.H., Goddeeris, B., Goethals, P.L.M. \& De Pauw, N. (2004). Potential of bio-indication of chironomid communities for assessment of running water quality in Flanders (Belgium). Belgian Journal of Zoology, 134(1), 31-40.

Akay, E. \& Dalkıran, N. (2019). Assessing biological water quality of Yalakdere stream (Yalova, Turkey) with benthic macroinvertebratebased metrics. Biologia, 1-17. DOI:10.2478/s11756-019-00387-9

Anonymous. (2015). Yerüstü Su Kalitesi Yönetmeliği. Resmi Gazete, pp. 130.

Anonymous. (2016). Yerüstü Su Kalitesi Yönetmeliğinde Değişiklik Yapılmasına Dair Yönetmelik. Resmi Gazete, pp. 134-149.

AQEM Consortium. (2002). Manual for the application of the AQEM system. A comprehensive method to assess European streams using benthic and 20 have Class IV water quality and were heavily polluted. Site 16 and 20 were situated after dam and regulator respectively. Habitat degradation was also detected in the stream beds of these two sites. These four sites have the least number of genera (1). Chironomidae gen sp, Dicranota $\mathrm{sp}$. and Tabanus sp. were collected from these sites. The conditions of Site 4, 5, 16 and 20 are suitable for these three taxa. The results of biodiversity indices reflected the degradation in habitats correctly in this study.

According to the results of the study, it was determined that Yeşilımak River and its tributaries were affected by urbanization, organic pollution draining from agricultural areas and domestic wastewaters. In addition, presence of dams, water regulators and hydroelectric power plant on the river caused changes in channel structure, temperature regime and sediment loading in Yeşilırmak River. All these changes negatively affected the water quality and Diptera community structure in almost all studied sites.

The one of the most important threat to aquatic ecosystems is anthropogenic activities in recent years. Due to these activities, Yeşilırmak River has also been heavily damaged. If these destructions continue and the necessary precautions are not taken, there will be irretrievable effects on the water quality and biodiversity of Yeşilırmak River and tributaries. Therefore, protecting water resources, preventing, and controlling the pollution, physicochemical and biological monitoring of the water quality are very important. In addition, much more research is needed to get more detailed information about the Diptera fauna of Yeşilımak River.

\section{ACKNOWLEDGEMENTS}

This research was supported by Hacettepe University Scientific Research Projects Coordination Unit (Project title: "Constitution of biotic index for long-term biomonitoring of water quality for Yeşillımak River by using benthic macroinvertebrates", Project leader: Prof. Dr. Nilgün Kazancı and Project no: 0701601 005).

macroinvertebrates, developed for the purpose of the Water Framework Directive.

AQEM Consortium. (2006). The AQEM river assessment program ASTERICS: A calculation program designed to assess the Ecological Quality of stream types in European countries based on macroinvertebrate taxa lists.

Armitage, P.D., Pinder, L.C. \& Cranston, P.S. (1995). The Chironomidae: Biology and ecology of non-biting midges. Springer Netherlands. DOI:10.1007/978-94-011-0715-0

Arslan, N., Kökçü, C.A. \& Mercan, D. (2016). Aquatic Oligochaetes Biodiversity in Turkey: Example of Lake Sapanca with Application of the Biotic Indices. International Journal of Advances in Chemical Enginering and Biological Sciences, 3(1), 27-31. DOI:10.15242/IJACEBS.AE0216131

Arslan, N., Salur, A., Kalyoncu, H., Mercan, D., Barışık, B. \& Odabaşı, D.A. (2016). The use of BMWP and ASPT indices for evaluation of water 
quality according to macroinvertebrates in Küçük Menderes River (Turkey), 71(1), 49-57. DOI:10.1515/biolog-2016-0005

Başören, Ö. \& Kazancı, N. (2016). Water quality assessment of Fırtına Stream (Rize, Turkey) by using various macroinvertebrate based metrics and physicochemical variables. Review of Hydrobiology, 9(1), 1-16.

Bolat, H.A., Kazanci, N., Basoren, O. \& Türkmen, G. (2016). Aquatic Diptera (Insecta) fauna of streams in the Eastern Black Sea Region of Turkey and their relationship with water quality. Review of Hydrobiology, 9(1), 47-72.

Bouchard, R.W.J. (2004). Diptera (Aquatic \& Semiaquatic True Flies). In Guide to aquatic macroinvertebrates of the Upper Midwest (pp. 159183). Water Resources Center, University of Minnesota.

Bulankova, E. (2003). Communities of diptera (excl. Chironomidae and Simuliidae) of the Gidra River basin. Acta Zoologica, 45, 85-94.

Buss, D.F., Carlisle, D.M., Chon, T.S., Culp, J., Harding, J.S., Keizer-Vlek, H.E., ... Hughes, R.M. (2015). Stream biomonitoring using macroinvertebrates around the globe: a comparison of large-scale programs. Environmental Monitoring and Assessment, 187(4132), 1-21. DOI:10.1007/s10661-014-4132-8

Car, M., Mohrig, W., Moog, O., Oosterbroek, P., Reusch, H., Wagner, R. \& Zwick, P. (1995). Diptera (except Chironomidae) (authors depending on family). In O. Moog (Ed.), Fauna Aquatica Austriaca (1995th, 2002nd ed., p. 98). Wien: Wasserwirtschaftskataster, Bundesministerium für Land-und Forstwirtschaft, Umwelt und Wasserwirtschaft.

Council of European Communities. (2000). Water Framework Directive (WFD) Directive 2000/60/EC of the European Parliament and of the Council of 23 October 2000 establishing a framework for Community action in the field of water policy. Official Journal of the European Communities (Vol. L327).

Courtney, G.W. \& Merritt, R.W. (2008). Aquatic Diptera. In R. W. Merritt, K. Cummins, \& M. B. Berg (Eds.), An Introduction to the Aquatic Insects of North America (pp. 687-722). Dubuque, lowa, US: Kendall/Hunt Publishing Co.

Courtney, G.W., Pape, T., Skevington, J.H. \& Sinclair, B.J. (2017). Biodiversity of Diptera. In Insect Biodiversity (pp. 229-278). John Wiley \& Sons, Ltd. DOI:10.1002/9781118945568.ch9

CSN 75 7716. (1998). Water quality, biological analysis, determination of saprobic index. Prague: Czech Technical State Standard, Czech Standards Institute.

Dash, M. C. (2003). Fundamental of Ecology. Tata Mcgraw Hill Publication.

De Oliveira, R.B.D.S., Mugnai, R., Pereira, P.D.S., De Souza, N.F. \& Baptista, D.F. (2019). A predictive multimetric index based on macroinvetebrates for Atlantic Forest wadeable streams assessment. Biota Neotropica, 19(2), e20180541. DOI:10.1590/1676-0611-BN-2018-0541

Domagalski, J.L. \& Johnson, H. (2012). Phosphorus and Groundwater: Establishing Links Between Agricultural Use and Transport to Streams. U.S. Geological Survey Fact Sheet 2012-3004.

Dubrovsky, N.M., Burow, K.R., Clark, G.M., Gronberg, J.M., Hamilton, P.A., Hitt, K.J., ... Wilber, W.G. (2010). The quality of our Nation's waters Nutrients in the Nation's Streams and Groundwater, 1992 - 2004. U.S. Geological Survey Circular 1350.

Duran, M. \& Akyıldı, G.K. (2011). Evaluating Benthic Macroinvertebrate Fauna and Water Quality of Suleymanli Lake (Buldan-Denizli) in Turkey. Acta Zoologica Bulgarica, 63(2), 169-178.

Ekingen, P. \& Kazancı, N. (2012). Benthic macroinvertebrate fauna of the Aksu Stream (Giresun, Turkey) and habitat quality assessment based on European Union Water Framework Directive criteria. Review of Hydrobiology, 5(1), 35-55.

Epler, J.H. (2001). Identification manual for the larval Chironomidae (Diptera) of North and South Carolina.

Feld, C.K., Kiel, E. \& Lautenschläger, M. (2002). The indication of morphological degradation of streams and rivers using Simuliidae.
Limnologica - Ecology and Management of Inland Waters, 32, 273-288. DOI:10.1016/S0075-9511(02)80033-0

Ferrington, L.C. (2008). Global diversity of non-biting midges (Chironomidae; Insecta-Diptera) in freshwater. Hydrobiologia, 595, 447-455. DOI:10.1007/978-1-4020-8259-7 45

Frutiger, A. \& Niederhauser, D. (2000). Effects of water abstraction on netwinged midges (Diptera: Blephariceridae). Internationale Vereinigung Für Theoretische Und Angewandte Limnologie: Verhandlungen, 27(2), 943-946. DOI:10.1080/03680770.1998.11901379

Fuhrer, G.J., Gilliom, R.J., Hamilton, P.A., Morace, J.L., Nowell, L.H., Rinella, J.F., ... Wentz, D.A. (1999). The Quality of Our Nation's Water: Nutrients and Pesticides. U.S. Geological Survey Circular 1225.

Gelhaus, J.K. (1986). Larvae of the Crane fly genus Tipula in North America (Diptera: Tipulidae). The University of Kansas Science Bulletin, 53(3), 121-182.

Godfrey, P.J. (1978). Diversity as a measure of benthic macroinvertebrate community response to water pollution. Hydrobiologia, 57(2), 111-122. DOI:10.1007/BF00016454

Gültutan, Y. \& Kazancı, N. (2009). A research on Chironomidae (Diptera) Fauna of Eastern Blacksea Region and water quality relationship. Review of Hydrobiology, 2(1), 57-80.

$\mathrm{HACH}$. (2005). DR/890 Datalogging colorimeter handbook procedures manual.

Hatch, L.K., Reuter, J.E. \& Goldman, C.R. (1999). Daily phosphorus variation in a mountain stream. Water Resources Research, 35(12), 3783-3791. DOI:10.1029/1999WR900256

Hilsenhoff, W.L. (2001). Diversity and Classification of Insects and Collembola. In Ecology and Classification of North American Freshwater Invertebrates (pp. 661-731). Academic Press. DOI:10.1016/B978-012690647-9/50018-1

Holman, I.P., Whelan, M.J., Howden, N.J.K., Bellamy, P.H., Willby, N.J., Rivas-Casado, M. \& McConvey, P. (2008). Phosphorus in groundwater-an overlooked contributor to eutrophication? Hydrological Processes Process, 22, 5121-5127. DOI: $10.1002 /$ hyp.7198

Ivković, M. \& Ivanković, L. (2019). The genus Dixa (Diptera, Dixidae) in Croatian lotic habitats, with a checklist of species and relationships with the fauna of neighbouring countries. ZooKeys, 867, 45-54. DOI:10.3897/zookeys.867.36613

Johnson, R.K., Hering, D., Furse, M.T. \& Verdonschot, P.F.M. (2006). Indicators of ecological change: Comparison of the early response of four organism groups to stress gradients. Hydrobiologia, 566(1), 139152. DOI:10.1007/s10750-006-0100-9

Kazanci, N., Başören, Ö., Türkmen, G., Öz, B., Ekingen, P. \& Bolat, H. A. (2013). Assessment of macroinvertebrate community structure and water quality of running waters in Camili (Artvin, Turkey); a part of Caucasus Biodiversity Hotspot, by using Water Framework Directive ( WFD ) methods. Review of Hydrobiology, 6(2), 91-102.

Kazanci, N., Ekingen, P., Türkmen, G., Ertunç, Ö., Dügel, M. \& Gültutan, Y. (2010). Assessment of ecological quality of Aksu Stream (Giresun, Turkey) in Eastern Black Sea Region by using Water Framework Directive (WFD) methods based on benthic macroinvertebrates. Review of Hydrobiology, 3(2), 165-184.

Kazanci, N. \& Ertunç, Ö. (2010). Use of Simuliidae (Insecta, Diptera) species as indicators of aquatic habitat quality of Yeşilırmak River Basin (Turkey). Review of Hydrobiology, 3(1), 27-36.

Kazanci, N., Türkmen, G. \& Başören, Ö. (2015). Application of BMWP and using benthic macroinvertebrates to determine the water quality of a transboundary running water, Çoruh River (Turkey). Review of Hydrobiology, 8(2), 119-130.

Kazanci, N., Türkmen, G., Ekingen, P. \& Başören, O. (2017). Evaluation of Plecoptera (Insecta) community composition using multivariate technics in a biodiversity hotspot. International Journal of Environmental Science and Technology, 14, 1307-1316. DOI:10.1007/s13762-017-1245-y

Kazanci, N., Türkmen, G., Ekingen, P. \& Başören, Ö. (2013). Preparation of a biotic index (Yeşilırmak-BMWP) for water quality monitoring of 
Yeşilırmak River (Turkey) by using benthic macroinvertebrates. Review of Hydrobiology, 6(1), 1-29.

Kazanci, N., Türkmen, G., Ertunç, Ö., Ekingen, P., Öz, B. \& Gültutan, Y. (2010). Assessment of ecological quality of Yeşilırmak River (Turkey) by using macroinvertebrate-based methods in the content of Water Framework Directive. Review of Hydrobiology, 3(2), 89-110.

Kazancı, N. \& Ertunç, Ö. (2008). On the Simuliidae (Insecta, Diptera) Fauna of Turkey. Review of Hydrobiology, 1(1), 27-36.

Kocataş, A. (2006). Ekoloji ve Çevre Biyolojisi (9. Baskı). Ege Üniversitesi Su Ürünleri Fakültesi Yayınları.

Kolcsár, L.P., Soos, A., Török, E., Graf, W., Rákosy, L. \& Keresztes, L. (2017). New faunistic records of the genus Erioptera Meigen (Limoniidae, Diptera, Insecta) from Europe. Entomologica Romanica, 21 , 23-44. DOI:10.24193/entomolrom.21.4

Kovac, D. \& Rozkošný, R. (2005). Insecta: Diptera, Stratiomyidae. In C. M. Yule \& H. S. Yong (Eds.), Freshwater Invertebrates of the Malaysian Region (pp. 798-804). Academy of Sciences Malaysia.

Lautenschläger, M. \& Kiel, E. (2005). Assessing morphological degradation in running waters using Blackfly communities (Diptera, Simuliidae): Can habitat quality be predicted from land use? Limnologica - Ecology and Management of Inland Waters, 35(4), 262-273. DOl:10.1016/j.limno.2005.04.003

Lechthaler, W., Moog, O. \& Car, M. (2017). Diptera: Simuliidae. In O. Moog \& H. Anne (Eds.), Fauna Aquatica Austriaca (Third edit, p. 11). Bundesministerium für Land- und Forstwirtschaft, Wien.

Luoto, T.P. (2011). Indicator value of midge larvae (Diptera: Nematocera) in shallow boreal lakes with a focus on habitat, water quality, and climate. Aquatic Insects, 33(4), 351-370. DOI:10.1080/01650424.2011.640333

Malmqvist, B., Zhang, Y. \& Adler, P.H. (1999). Diversity, distribution and larval habitats of North Swedish blackflies (Diptera: Simuliidae). Freshwater Biology, 42(2), 301-314. DOI:10.1046/j.1365-2427.1999.444497.x

Margalef, R. (1958). Information theory in Ecology. General Systems, 3, 3671.

Mason, C.F. (2002). Biology of freshwater pollution. Harlow, England; New York : Prentice Hall.

Middlekauff, W.W. \& Lane, R.S. (1980). Adult and immature Tabanidae (Diptera) of California. University of California Press.

Paine, G. H., And, J. R., Gaufin, A.R. \& Taft, R.A. (1956). Aquatic Diptera as indicators of pollution in a Midwestern Stream. The Ohio Journal of Science, 56(5), 291-304.

Podeniene, V. \& Gelhaus, J. K. (2015). Review of the last instar larvae and pupae of Hexatoma (Eriocera) and Hexatoma (Hexatoma) (Diptera, Limoniidae, Limnophilinae). Zootaxa, 4021(1), 93-118. DOI:10.11646/zootaxa.4021.1.4

Ravera, O. (2001). A comparison between diversity, similarity and biotic indices applied to the macroinvertebrate community of a small stream: the Ravella River (Como Province, Northern Italy). Aquatic Ecology, 35(2), 97-107. DOI:10.1023/A:1011433813309

Rekolainen, S. (1989). Effect of snow and soil frost melting on the concentrations of suspended solids and phosphorus in two rural watersheds in Western Finland. Aquatic Sciences, 51(3).
Reusch, H. \& Oosterbroek, P. (1997). Diptera Limoniidae and Pediciidae, short-palped Crane Flies. In A. Nilsson (Ed.), Aquatic insects of North Europe. A taxonomic handbook (Vol. 2, pp. 105-132). Stenstrup: Apollo Books.

Rosenberg, D.M. \& Resh, V.H. (1993). Introduction to Freshwater Biomonitoring and Benthic Macroinvertebrates. In Rosenberg and Resh (Ed.), Freshwater Biomonitoring and Benthic Macroinvertebrates (pp. $1-$ 9). New York : Chapman \& Hall.

Schmedtje, U. \& Colling, M. (1996). Okologische Typisierung der aquatischen Makrofauna. Bayerisches Landesamt für Wasserwirtschaft.

Šporka, F. (2003). Vodne bezstavovce (makroevertebrata) Slovenska, supis druhov a autekologicke charakteristiky. Slovak Aquatic Macroinvertebrates Checklist and Catalogue of Autecological Notes. Bratislava.

Tachet, H., Richoux, P., Bournaud, M., Usseglio-Polatera, P., \& Impr. Laballery). (2010). Invertébrés d'eau douce systématique, biologie, écologie. CNRS Editions.

Thirion, C. (2016). The determination of flow and habitat requirements for selected riverine macroinvertebrates. North-West University.

Türkmen, G.- \& Kazancl, N. (2015). Determining the Reference Ephemeroptera Communities in the Eastern Part of the Black Sea Region for the Implementation of the Water Framework Directive in Turkey. Transylvanian Review of Systematical and Ecological Research, 17(1), 177-194.

Türkmen, G. \& Kazancı, N. (2016). Habitat quality assessment of streams in Altindere Valley (Trabzon, Turkey) by using physico-chemical variables and various biotic indices based on benthic macroinvertebrates. Review of Hydrobiology, 9(1), 17-36.

Ujvárosi, L. \& Bálint, M. (2012). Discovery of the second European Amalopis species: An integrative survey of the widespread Pedicia (Amalopis) occulta (Meigen, 1830) (Insecta, Diptera, Pediciidae). Zootaxa, 3189, 128. DOl:10.11646/zootaxa.3189.1.1

Ujvárosi, L., Kolcsár, L. P., Bálint, M. \& Ciprian, M. (2010). Pediciidae larva (Insecta, Diptera) in the Carpathian basin: preliminary results and further perspectives. Acta Biologica Debrecina. Supplementum Oecologica Hungarica., 21, 233-246.

Wagner, R., Barták, M., Borkent, A., Courtney, G., Goddeeris, B., Haenni, J.P., ... Zwick, P. (2008). Global diversity of dipteran families (Insecta Diptera) in freshwater (excluding Simulidae, Culicidae, Chironomidae, Tipulidae and Tabanidae). In Freshwater Animal Diversity Assessment (pp. 489-518). Springer Netherlands. DOI:10.1007/978-1-4020-8259-7_49

Wotton, Roger S. \& Malmqvist, B. (2001). Feces in Aquatic Ecosystems. BioScience, 51, 537-544. DOI:10.1641/0006-3568(2001)051[0537:FIAE]2.0.CO;2

Zeybek, M. (2017). Macroinvertebrate-based biotic indices for evaluating the water quality of Kargı Stream (Antalya, Turkey). Turkish Journal of Zoology , 41, 476-486. DOI:10.3906/zoo-1602-10

Zeybek, M., Kalyoncu, H., Karakaş, B. \& Özgül, S. (2014). The use of BMWP and ASPT indices for evaluation of water quality according to macroinvertebrates in Değirmendere Stream (Isparta, Turkey). Turkish Journal of Zoology, 38, 603-613. DOI:10.3906/zoo-1310-9

Zwick, P. (1977). Australian Blepariceridae (Diptera). Australian Journal of Zoology Supplementary Series, 25(46), 1. DOI:10.1071/ajzs046 